\title{
Editorial
}

Misconceptions and ill-founded theories can arise in all areas of science. However, the apparent accessibility of many epidemiology findings and popular interest in the subject can lead to additional misunderstandings. The article below continues an occasional series of short editorials highlighting some current misinterpretations of epidemiological findings. Invited authors will be given wide scope in judging the prevalence of the misconception under discussion. We hope that this series will prove instructive to cancer researchers in other disciplines as well as to students of epidemiology.

\section{That lung cancer incidence falls in ex-smokers: misconceptions 2}

\author{
J Peto*,I \\ 'London School of Hygiene and Tropical Medicine, Keppel St., London WCIE 7HT, UK
}

British Journal of Cancer (20II) I 04, 389. doi: I0.1038/sj.bjc.6606080 www.bjcancer.com

(c) 201। Cancer Research UK

There is a widespread misconception in the general population, and even among some epidemiologists, that the incidence rate of lung cancer declines in ex-smokers. In fact, when smoking ceases, the rate stops increasing steeply and remains almost constant (Figure 1: Halpern et al, 1993). This misconception presumably arose because the relative risk falls rapidly in ex-smokers, as it is calculated by dividing the roughly constant ex-smokers' rate by the rising rate in non-smokers. (Whether the slight increase in incidence after stopping smoking is greater than the increase in non-smokers of the same age, as Figure 1 suggests, may never be known. Many ex-smokers relapse, and some may fail to admit it.) The lifelong increased risk in those who started smoking when they were very young indicates that smoking initiates lung carcinogenesis, but the incidence pattern in ex-smokers is particularly informative. The immediate effect of stopping suggests that smoking also acts at a late stage in carcinogenesis, but as the rate does not fall when smoking ceases it seems that the final event that a cell must undergo to become fully malignant is unaffected by smoking (Cairns, 2006). The age distribution of cancer, and particularly of lung cancer in smokers and non-smokers, led to multi-stage models of carcinogenesis long before altered genes were observed in human cancer (Armitage and Doll, 1954;

\section{REFERENCES}

Altshuler B (1989) Quantitative models for lung cancer induced by cigarette smoke. Environ Health Perspect 81: 107-108

Armitage P, Doll R (1954) The age distribution of cancer and a multi-stage theory of carcinogenesis. Br J Cancer 8: 1-12. Reprinted 2004 in Br J Cancer 91: $1983-1989$

Cairns J (2006) Cancer and the immortal strand hypothesis. Genetics 174: $1069-1072$

Doll R (1978) An epidemiological perspective of the biology of cancer. Cancer Res 38: $3573-3583$

\footnotetext{
*Correspondence: Professor J Peto; E-mail: julian.peto@|shtm.ac.uk
}

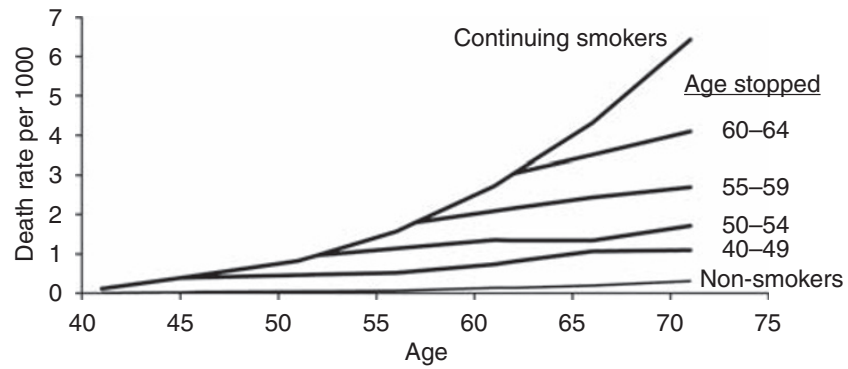

Figure I Lung cancer mortality in continuing smokers, ex-smokers and non-smokers. Data from Halpern et al (1993).

Doll, 1978). Various alternative models have been proposed (Altshuler, 1989; Samet et al, 2007), and which (if any) is correct must ultimately be decided from molecular rather than statistical studies. Molecular biologists should, however, be aware of these epidemiological observations, as they must be relevant to understanding the significance of the somatic changes in lung cancer that are now being discovered (Pleasance et al, 2010).
Halpern MT, Gillespie BW, Warner KE (1993) Patterns of absolute risk of lung cancer mortality in former smokers. J Natl Cancer Inst 85: 457-464 Pleasance ED, Stephens PJ, O'Meara S, McBride DJ, Meynert A, Jones D, Lin ML, Beare D, Lau KW, Greenman C, Varela I, Nik-Zainal S, Davies HR, Ordoñez GR, Mudie LJ, Latimer C, Edkins S, Stebbings L, Chen L, Jia M, Leroy C, Marshall J, Menzies A, Butler A, Teague JW, Mangion J, Sun YA, McLaughlin SF, Peckham HE, Tsung EF, Costa GL, Lee CC, Minna JD, Gazdar A, Birney E, Rhodes MD, McKernan KJ, Stratton MR, Futreal PA, Campbell PJ (2010) A small-cell lung cancer genome with complex signatures of tobacco exposure. Nature 463: 184- 190 Samet JM, Thun MJ, Berrington de Gonzales A (2007) Models of smoking and lung cancer risk-a means to an end. Epidemiology 18: 649-651 